\title{
Republican Home-".0wning
}

\section{Robert Hockett ${ }^{*}$}

Ten years after failing and being rescued by our federal government, our nation's principal secondary market makers in home mortgage loans Fannie Mae and Freddie Mac - remain in federal receivership. The proximate reason for this is that neither Republicans nor Democrats in Congress have been able to find consensus - interparty or intraparty consensus - on what should be done with our home mortgage GSEs post-"crisis. The deeper reason is that public - that is to say, citizen - ownership of secondary market makers in home loans is in a certain sense 'natural' in any republic, such as our own, where both middle class standing and that standing's primary indicator home--owning - are deeply ingrained in the citizenry's self-ascribed national identity. This truth is yet more compelling when home prices, as they are bound to do anywhere homes are the primary middle class asset, become what I call 'systemically significant' --- that is, when they become pervasive determinants both of other prices and of broader macroeconomic wellbeing. I conclude that the only sustainable future for Fannie and Freddie, not to say for the American middle class and our other GSEs (including our student loan GSEs), is to be found in their past. Fannie and Freddie should be forthrightly made citizen-owned once again as Fannie was through our home markets' healthiest decades.

\section{Introduction}

Ten years after failing and being rescued by our federal government, our nation's principal secondary market makers in home mortgage loans - Fannie Mae and Freddie Mac - remain in federal receivership. The proximate reason for this is that neither Republicans nor Democrats in Congress have been able to come to consensus - interparty or intraparty consensus - on what should be done with the home mortgage government--sponsored entities ('GSEs') post-.crisis. The deeper reason, I'll argue here, is that public - that is to say, citizen - ownership of secondary market makers in home loans is in a certain sense 'natural' in any republic, such as ours, in which both middle class standing and that standing's primary indicator home-:-owning - are deeply ingrained in the citizenry's self-ascribed national identity.

Edward Cornell Professor of Law, Cornell University; Consulting Counsel, Westwood Capital; Founding Board Member, Digital Fiat Currency Institute. Formerly Federal Reserve 
In this sense, Fannie's and Freddie's 2008 falling into federal receivership is best understood as a form of 'reversion to the mean,' the 'mean' here being intimate public involvement both in fostering and maintaining a 'yeoman' - that is, middle class - republic as a general matter, and in fostering and facilitating, pursuant to that general project, home--owning across the broadest possible swathe of the populace as a particular matter. And this means the most sensible 'wind--down' of Fannie's and Freddie's receivership by our federal government will be a re-.institutionalization of Fannie's and Freddie's forthright ownership by our federal government - which is, after all, simply that collective instrumentality, 'owned' and operated by all of us for the benefit of each of us, possessed of the most general national jurisdiction.

I'll proceed, then, as follows. First I will briefly elaborate the American polity's self-conception as a 'republic of owners,' as manifest in its now centuries' long tradition of republican ideology and associated ownership.-spreading public policy. Then I'll more carefully treat of our home--spreading history in particular, focusing especially on the origins and first sixty years of the principal public home-spreading instrumentalities still with us - FHA, Fannie, Freddie Mac, and Ginnie Mae. After that I'll discuss the particularly poignant and yet overlooked financial side of American home--owning, concentrating in particular on home prices' status, in any middle class republic, as what I elsewhere call 'systemically important prices,' or 'SIPIs.'

I'll then conclude that our traditions and ideological commitments, in conjunction with the aforementioned financial entailments of those commitments, yield but one unavoidable policy upshot - namely, that home mortgage finance instrumentalities should be publicly owned and operated. They amount, in effect, to the most important public utility that our public possesses, short of our central bank and our federal government itself.

\section{An Owners' Republic: Core Assets, Income-Compositional Symmetry, and Macro-"Stability}

When Americans read the literature of the late colonial and or early national periods of their history, they encounter frequent use of the word 'republic.' Few of 
us likely pause any longer to ponder, however, what that word meant or still means. As it happens, however, the word means a lot. ${ }^{1}$

The founders, and both the national self-.image and the associated policy tradition they left us, were pervasively informed by a revival of sorts. This was a revival of the civic republican tradition of pre-.imperial Rome (perhaps most memorably espoused by Cicero). The revival began in the early modern period in Italy (Guicciardini, Machiavelli), spread northward to the Netherlands, France, and Great Britain (Grotius, Montesquieu, Harrington, Bolingbroke), and then westward to the British colonies in North America.

Like other ideologies, Republicanism offered a vision of what an ideal set of social, economic, and political arrangements would look like. Central to the Republican vision was a polity - a res publica, or 'public thing' - constituted by productive, responsible, materially independent citizens. Citizens would be materially independent in that they would own the means of their own material sustenance. In that sense, each citizen would constitute a sort of quasi--autarkic 'private sphere' of ownership ('privation' denotes the lack of such ownership), while the 'public sphere' would be the domain in which those private citizens had to act collectively rather than individually in order fully to secure the 'fruits of liberty' and the 'pursuit of happiness.' Hence the state amounted, in the language of contemporary economic thought, to a means of addressing collective action problems. It was a site of collective agency, through which citizens jointly could secure the background conditions necessary to their flourishing severally.

This background ideal is key both to understanding what the founders were on about when they extolled the Jeffersonian ideal of a 'yeoman republic' or the Hamiltonian vision of a 'commercial republic,' and to understanding what both they and their successors were trying to effect through the many policy choices they made through the late $18^{\text {th }}$, the $19^{\text {th }}$, and the $20^{\text {th }}$ centuries. ${ }^{2}$ The Bill of Rights and the Guarantee Clause of the U.S. constitution, and American property law, education policy, and even most social welfare policy, all were about (a) widely dispersing what I call 'core assets' of the kind necessary to maintaining a productive and materially independent citizenry, and (b) maintaining a mode of collective self-.-

1 This section draws in part upon my forthcoming book, A Republic of Owners (Yale U. Press, 2019).

2 Id. See also Drew R. McCoy, The Elusive Republic: Political Economy in Jeffersonian America (1980). 
governance pursuant to which independent citizens could collaborate in addressing truly collective challenges on terms of equal voice and mutual respect.

The assets required to realize this ideal, characterized at the appropriate level of generality, are the same now as they were in the pre -modern era. They are (a) suitable shelter and sustenance, (b) productive capital, and (c) the human capital - that is, the education - necessary for anyone actually to use productive capital productively. We can think of these categories as 'legs,' so to speak, of that 'three-legged stool' on which any successful, sustainable republic must rest if it isn't to topple.

What these three general categories specifically embrace, on the other hand, unsurprisingly varies across time and space with what technologies of production locally predominate. The 'legs of the stool,' in other words, will be fashioned of different materials according as the economy of the republic in question is agrarian, industrial, 'post-industrial,' or of some other sort. This is simply because what kinds of shelter are 'suitable,' what forms of capital are 'productive,' and what sorts of education are 'adapted' to mastery of productive capital all ride on what is produced and how it is produced in a given time and place.

From the late $18^{\text {th }}$ to early $20^{\text {th }}$ centuries, when American productive activity was still largely agrarian in character, the first two core assets - shelter and sustenance along with productive capital - significantly coincided in the U.S. To spread land-..ownership was in effect to spread both home ownership and productive capital ownership. Human capital, for its part, could be spread by publically providing education that was itself largely agricultural in orientation once primary schooling was completed. Early American abolishment of fee tail as a form of land tenure, followed by the Northwest Ordinance at the end of the $18^{\text {th }}$ century and sundry 'Land Acts' promulgated into the 1820s, were classic examples of early American land--spreading policy. Publicly provided primary and secondary education, along with the apprentice system, were classic examples of education-spreading policies. ${ }^{3}$

The apogee of republic--maintaining policy in the immediately pre--modern era, however, was reached in the paired Homestead and Land Grant Acts of the late-.mid-1 $19^{\text {th }}$ through the early $20^{\text {th }}$ centuries. It is no accident that these bills were enacted together. They spread the then-most important sheltering and productive asset - land - on condition of recipients' making it productive, and spread the

3 Again, details can be had in Hockett, supra note 1. 
educational wherewithal, via Land Grant universities and associated 'cooperative extension' programs, to make it productive. It is also no accident that these programs were initiated and ultimately instituted by a Congress that was in the hands of a new political party that called itself 'Republican.' Nor is it accidental that this party and our nation were then led by a President, Abraham Lincoln, whose celebrated Cooper Union address had declared that to make the United States a nation of 'free men' would require both the emancipation of slaves and the provision of all men with the tools necessary to ply their trades independently of the inherently dependent employment relation. ${ }^{4}$

It is impossible to take--in the full portfolio of pre--modern American ownership-'spreading policies without being impressed by its coherence and comprehensiveness. It is almost as if policymakers all along were subconsciously acting upon an ideal that I elsewhere call 'the income-.-compositional symmetry principle,' which we can think of as the core idea of what I call 'republican macroeconomics.' ${ }^{5}$ Pursuant to this ideal, each republican household's income stream approximates the land/capital/labor income composition of the republic's macroeconomy. Conformity to this ideal makes for a just, sustainable, and long..term efficient economic order. This it does by providing both (a) an equitable distribution of those basic assets that are requisite to material independence, and (b) stable because widely shared and hence consumption--supporting - macroeconomic growth. As productivity and production both grow in an income-.compositionally symmetrical economy, so does individual and hence aggregate absorptive capacity in that economy.

A sort of 'automatic Keynesianism' lies at the core of any such economy, bringing it into conformity with 'Say's Law' in a manner that no income.-. compositionally asymmetric economy can long manage. ${ }^{6}$ The associated benefits of social solidarity, stability, and non-"precarity among 'stakeholder-.citizens' that come with such conformity also are precious achievements, both in their own right and as the substrate of any healthy, sustainable, and enduring republic. Such stakeholder citizens, whom Thomas Jefferson famously dubbed our 'sturdy yeomanry,' nowadays bear a more contemporary-.ringing name. We call them the middle class.

4 See again Hockett, supra note 1. Also Eric Foner, Free Soil, Free Labor, Free Men: The Ideology of the Republican Party Before the Civil War(1970).

5 Income--Compositional Symmetry is the guiding ideal at the core of the aforementioned book. See Hockett, A Republic of Owners, supra note 1.

6 See Hockett, supra note 1. Also Robert Hockett, 'What Kinds of Stock-"Ownership Plans Should There Be: Of ESOPs, Other SOPs, and "Ownership Societies,"' 92 Cornell Law Review 865 (2007). 
To foster and sustain a large and healthy middle class is to foster and sustain the very sine qua non of an enduring republic. And to do that requires that we foster and maintain an economy that approximates to conformity with the income-.compositional symmetry principle.

But this maintenance requires an ongoing exercise of collective agency. It is a matter of ongoing public maintenance of the background conditions necessary for private flourishing. ${ }^{7}$ All of us acting jointly, in other words, is prerequisite to each of us enjoying income--compositional symmetry severally. And this is what American public policy effectively strived for well into the $20^{\text {th }}$ century.

As the $20^{\text {th }}$ century loomed, however, agriculture and associated industries steadily diminished in relative importance. At the same time, we ran out of new land to distribute among our citizenry in any event. Interestingly, this is also when nation-wide under-consumption/over--production and associated financial crises, along with ensuing debt-.-deflationary slumps, began to strike the nation's economy. The crises of the early 1870s, the 1890s, 1907, and 1929 all greatly exceeded in magnitude all crises that had struck before, and each of these in turn was more calamitous than its predecessors. ${ }^{8}$

Our response was two--fold. First, we worked to keep spreading homes and human capital, only now by more explicitly financialized means. And second, we worked to spread at least the fruits of nonhuman capital, if not that capital itself, through collective bargaining, workplace regulation, small business facilitation, and redistributive taxation. Brandesian antitrust law, labor law, and progressive income and estate taxation, each introduced in the early decades of the $20^{\text {th }}$ century, all are best read in that light. All of these measures, especially in their most potent forms as developed during the New Deal era, worked to slow the steady drift further and further from income-compositional symmetry over the course of the $20^{\text {th }}$ century. ${ }^{9}$

But for reasons that I elaborate elsewhere - primarily a systematic republican preference for asset--owning over income-rerouting - these stopgap measures proved at best to be temporary salves. What will ultimately be required, as I also elaborate elsewhere, is a comprehensive retooling of our primary modes of core--asset--spreading, especially nonhuman-.capital--spreading. Ironically, however,

7 More on these background conditions and the need of collective agency to assure them infra, Sections 2 and 3.

8 See again Hockett, supra note 1. Also Robert Hockett, 'A Jeffersonian Republic by Hamiltonian Means,' 79 University of Southern California Law Review 973 2006).

$9 \quad$ Id. 
the way forward where home--. and higher-meducation--spreading are concerned is the way back. It is to return to the financial mode of collective core asset provisioning that we developed in the early-mid.- and mid.-20 $20^{\text {th }}$ century to spread homes and higher education, respectively. In the remainder of this paper I concentrate on the first of these.

\section{Republican HomemFinance: Paradise Lost, Found, and Squandered}

As noted above, suitable housing amounts to what I call a 'core asset' in republican ideology. And in the early days of our republic, both this asset and a critical nonhuman capital asset both could be and were spread collectively in the form of arable land. With the coming of the $20^{\text {th }}$ century, however, new lands for distribution over the population grew scarce and land diminished in relative importance as a productive asset in any event. With that development, shelter-- and nonhuman.-capital-.provision separated into two distinct 'birds' that could no longer be 'hit with one stone.' Citizens no longer could purchase homes with 'debt' they paid down by homesteading - that is, by making their collectively conferred lands productive - but had to resort to new, now-.more mamiliar forms of debt instead.

The transition from labor $\cdots$ debt home $\cdots$ finance to mortgage $\cdots$ debt homedid not commence smoothly. ${ }^{10}$ Early in the $20^{\text {th }}$ century as now, most who purchased residential real estate did so largely on credit. What was different was that fewer, for that reason, purchased housing at all. Thanks in part to the vagaries of state property law and in part to restrictions on interstate banking, mortgage credit markets were more fragmented, and mortgages in consequence less liquid investments, than they have since become. Home loans in consequence were extended for much briefer terms - generally two to three years, seldom more than five years - at the end of which they would 'balloon' to come due in full.

Loan-.'to-vvalue ratios before the 1930s, in turn, were accordingly quite low by contemporary standards. As little as fifty percent was considered high, and was rare. Financing on such terms not surprisingly fell short of most would -.be buyers' capacities unless loans could be refinanced. Frequent rollover financings were thus the norm. This wasn't particularly problematic for buyers so long as credit markets functioned smoothly and home prices remained stable or continued to rise, as they did - rapidly - well into the 1920s after the First World War. Refinancing then, as

10 The following paragraphs draw in part upon Robert Hockett, 'A Jeffersonian Republic by Hamiltonian Means,' supra note 8. 
more recently, was not difficult when credit was abundant and the value of one's collateral - the home itself - continued to rise in the real estate boom of the ' 20 s.

When U.S. residential real estate prices leveled off and then began falling in the late-mid--1920s, however, short-term mortgage loans no longer could be refinanced in full. Resultant forced sales and foreclosures, which reached the rate of over 1,000 per day once some $50 \%$ of all home mortgages in the country had gone into delinquency or default, pulled prices steadily lower. American real estate markets fell into the now-familiar 'downward spiral.' Rising defaults brought less willingness or capacity to refi, which brought on more defaults, ... and so on. The parallel with our more recent crisis some 80 years later could hardly be more striking.

Indeed, more parallels proliferate. For in the late 1920s also, as in 2008, the crisis that afflicted the real estate market spread far more widely, ultimately reaching the banking and securities markets themselves. The reasons were not hard to find. For one thing, upwards of $30 \%$ of the American labor force was employed either in the home-"building industry itself, or in industries that were bound to lose business as home-.-builders lost business. For another thing, of course, disemployed labor, like fearful and foreclosed mortgagees themselves, spent less money, feeding yet further contraction and yet more foreclosures. The vortex of 'crunch,' contraction, recession, and depression was on. It is surprising, against this backdrop, that during the dramas of 2008-09 parallels were routinely drawn to the 1929 stock market crash but not to much more momentous real estate crash that accompanied and fed into it.

In effect, what the experience of the late 1920s and early 1930s showed was that American home prices had become what I've elsewhere dubbed 'systemically important prices."11 They were now prices on which other prices, and on which macroeconomic stability more broadly, now critically depended. This in turn meant they were prices that we as a public could no longer afford to ignore, 'leave to the market,' or treat purely as 'private' in character. They were a matter of profound macroeconomic and hence public concern.

The programs instituted to address the early 1930s' real-"estate-"rooted crisis, which began in the last year of the Hoover administration, expanded through the Roosevelt years, and continue in altered form to this day, cannot fail to impress in

11 See Robert Hockett \& Saule Omarova, 'Systemically Significant Prices,' 2 Journal of Financial Regulation 1 (2016). 
their innovativeness and comprehensiveness. The process began with the Federal Home Loan Bank Act (FHLBA) of 1932, which authorized the establishment of a system of Regional Federal Home Loan banks roughly parallel to that of the Federal Reserve's system of Regional Federal Reserve Banks. The Regional FHL Banks provided standards and supervision to member institutions - the private mutual savings banks (MSBs) then responsible for most mortgage lending - and in return supplied added lines of credit on the security of mortgage loans that they held. This in effect monetized those mortgage loans much as the Fed monetizes Treasuries and some short-.term commercial paper.

The new Congress and President that took office in 1933 built upon Hoover's humble initiative. They did so first with a Home Owners' Loan Act (HOLA) in 1933, which temporarily established a Home Owners Loan Corporation (HOLC) for purchasing and refinancing foreclosed loans on favorable terms to enable erstwhile home--owners to recover their homes. It also pioneered the long-term self-amortizing fixed-rate mortgage loan via the terms of its refis, and laid the groundwork for a steady proliferation of more MSBs by directly affording federal charters even where state authorities might have barred entry.

One year after HOLA, the National Housing Act (NHA) of 1934 afforded a system of deposit insurance for the MSBs analogous to that newly instituted for depositors in commercial banks through the Federal Deposit Insurance Act, buttressing and thus further boosting the availability of deposits that provided liquidity enabling more lending. More critically, the NHA instituted a system of insurance for the MSBs themselves, against defaulting mortgagors: Section 203 of the Act established a nationwide 'mutual mortgage insurance system' through which a newly created, and in this case now permanent, Federal Housing Administration (FHA) could insure first lien mortgage loans made for the construction, purchase, or refinancing of one-to -..four bedroom family homes. In effect, FHA took over and discharged indefinitely the functions of the HOLC, which from its inception had been conceived as but ad hoc and temporary.

FHA still operates today, guaranteeing and, in many cases, originating or refinancing mortgage loans that conform to the prudent standards that it maintains (so-called 'conforming' mortgage loans). It also affords financial counseling to borrowers. And it has historically done this at a profit for the public fisc - with the Fed, one of but few federal instrumentalities to do so.

The FHA and its insurance program, building on HOLC's initiatives, fundamentally altered the regime of American home-.finance. It effectively replaced 
traditional over--collateralization requirements with collective default-risk-pooling, rendering home loans more affordable. The uniform requirements upon which HOLC and then FHA conditioned mortgage insurance, for their part, fostered the development of a standardized home mortgage loan instrument marketable throughout the country. This was the now-.familiar 30-year, fixed rate mortgage loan, which in view of the interest rate risk it entails probably could not have been privately developed or offered on anything like the scale to which we're accustomed. 12

This in turn opened the door to securitization and hence yet more complete risk-pooling, more on which presently. The housing quality requirements upon which FHA conditioned its insurance also ensured the financial rationality of federally facilitated home--finance investments. And FHA's requirements of (a) actuarial soundness, and (b) risk classifying and separate pooling ensured that the system retained the traditional efficiencies of a private insurance market while avoiding the dysfunctions to which for--profit motives in markets with scale economies give rise. ${ }^{13}$ That's how it managed consistently to operate in the black.

The Roosevelt Administration and Congress effectively completed their and the late Hoover Administration's ad hoc discovery of our now familiar method of financially engineered home-"-ownership-spreading in 1938, by chartering, through the Reconstruction Finance Corporation ('RFC'), the first modern 'government sponsored enterprise' ('GSE'). The Federal National Mortgage Association - FNMA, or 'Fannie Mae' - was charged with making a national secondary market in FHA-insured and, later, Veterans Administration-" ('VA-') insured mortgage instruments themselves - in effect, with securitizing those mortgages. ${ }^{14}$

12 It bears noting that apart from the U.S., only Denmark, whose 'covered bond' system in large measure functionally replicates our own mortgage finance system, uses primarily long.term mortgage loans like our own. On the 30 year fixed rate mortgage loan's dependence on public support, see, e.g., Mark Zandi \& Christian DeRitis, The Future of the Mortgage Finance System (2011). Also Mortgage Bankers Association, MBA's Recommendations for the Future Government Role in the Core Secondary Mortgage Market (2009). But see David Scharfstein \& Adi Sunderam, The Economics of Housing Reform (2011).

13 More on secondary mortgage markets' 'natural monopoly' characteristics infra, Section 3.

14 Strictly speaking, securitization proper began with the 'pass-..through' certificates introduced by Ginnie Mae, more on which infra, in 1970. Here I use 'securitization' more loosely, as a rough synonym for 'rendering liquid.' 
Fannie Mae along with later progeny (in particular Ginnie Mae and Freddie Mac, not to mention the later--established higher education loan securitizers like Sallie Mae, expressly patterned after the Fannie Mae model ${ }^{15}$ ) closed the proverbial circle, separately completing the markets for housing credit and credit-risk-"bearing, and thereby optimizing the availability of such credit to American home--buyers. Notably, no private securitizers had emerged before Fannie to discharge these functions, notwithstanding that the NHA of 1934 had authorized precisely that. The interest rate risk carried by any long-term instrument like the 30-year fixed-rate seems to have precluded that. ${ }^{16}$

Fannie Mae proved sufficiently successful, even on market terms, to quasi"privatize in 1968, though the Johnson Administration did so in order to offset the growth of the federal balance sheet occasioned by massive Vietnam war spending, apparently fearful as well that financial volatility earlier in 1966 might cause hiccups at Fannie. (Sallie Mae met a similar fate in late 2004, to offset the federal balance sheet expansion occasioned by another Texan President's war.)

Freddie, for is part, was instituted in 1970 specifically to operate in parallel to the newly quasi-privatized and gargantuan Fannie, while Ginnie Mae was established at the time of Fannie's privatization to retain a diminished number of mortgage loans in the portfolio of a still-publicly-owned GSE. Fannie, Freddie and Ginnie subsequently came to offer a multitude of home finance services, and all operated effectively, as well as reasonably profitably, in spreading home--ownership until halfway through the first decade of the present century.

The upshot of FHA's, Fannie's, then Freddie's and Ginnie's joint success was a remarkable achievement. Over the course of our new system's first 60 years, we were transformed from a society in which a bit over one-third of households owned their own homes to one in which over two thirds owned their own homes. We nearly doubled, in other words, the extent to which we were managing to spread the core republican asset of suitable housing. ${ }^{17}$

In addition, we had doubled the extent of American ownership of an at least partly income--generating asset. For homes generally rise gradually in value over time, such that non-recklessly levered purchases of them amounted to a form of sustainable wealth-growth among the latter-day American 'yeomanry' - our middle

15 See Hockett, Jeffersonian Republic, Hamiltonian Means, supra note 10.

16 See sources cited supra, note 12.

17 See again Hockett, sources cited supra, notes 1 and 8. 
class. ${ }^{18}$ And finally, because home prices grew steadily more systemically significant, in the sense I described earlier, over the course of the $20^{\text {th }}$ century, our public institutions of private home finance also operated as macroeconomic stabilizers, buffering middle class family net worth and well--being against fluctuations in other sectors of the American economy. In effect, FHA and our GSEs did for home prices what the Fed does with money-rental prices through open market operations.

What, then, went wrong? ${ }^{19}$ What changed after sixty odd years of republican home--spreading and price--maintaining success? In essence, the story is one of creeping privatization, deregulation, and attendant speculative-"profit--seeking, accompanied by classic asset price bubble dynamics that our principal money... modulator - the Fed - didn't see fit to tamp down till too late.

On the one hand, Fannie and Freddie fell under mounting investor pressure over the course of the later 1990s, even while continuing to enjoy implicit federal guarantees rooted in their sizes, histories, and original public missions - a classic case of 'moral hazard.' Their investors for their part were caught up in bubble psychology just like so many others, including the Fed Chairman, during the nation's housing price boom. It was very profitable to buy ever more risky, even non-FHA-conforming mortgage loans so long as property values kept growing at the rates that they grew in the late 1990s and early 2000s - rates not seen since the 1920s. Global investors in Fannie and Freddie, including many a large sovereign wealth fund or treasury, insisted these profits be sought, especially as the profits of more and more private label, adjustable--rate-"- mortgage securitizers sky-rocketed. ${ }^{20}$

On the other hand and at the same time, thanks to their original missions as engines of republican home--spreading, and thanks to growing home equity's capacity to function as a source of supplemental capital income during a long period of stagnating wages and salaries, members of Congress and other officials during the Clinton and Bush years alike, themselves evidently caught up in the belief that real estate prices 'could only go up,' in some cases actively pressured the old GSEs to take on more risky mortgages. Why not pursue the original salutary mission all the more aggressively, after all, if even the revered Fed Chairman was convinced that the markets were self-calibrating and that real estate 'could only go up,' and if their

18 Thus aiding in the cause of income compositional symmetry. See Hockett, A Republic of Owners, supra notes 1, 2, and accompanying text.

19 The following paragraphs draw upon Robert Hockett, 'Bailouts, Buy-.'Ins, and Ballyhoo,' 52 Challenge 36 (2009).

20 Id. 
doing so was the sole way to maintain sufficient aggregate demand to sustain macroeconomic growth and employment? Finally, in view of Fannie's and Freddie's aforementioned governmental lineage, 'implicit' guarantees, and associated 'too big to fail' status, both were all the more able to attract plenty of purchasers of their securities.

Ultimately, of course, all of this landed Fannie and Freddie in very hot water. The real estate slump that commenced in the summer of 2006 hit them hard. We know where it led. Millions of Americans lost their homes, trillions in wealth were lost, the nation sled into its first major debt-.deflation since the 1930s, and Fannie and Freddie were effectively renationalized in the early autumn of 2008.21

Many of course took this for an ominous sign, on all fours with the totterings of Bear Stearns, Countrywide, Lehman Brothers, Merrill Lynch, AIG, and Washington Mutual, among others, both immediately before and immediately after. What we ought really to see in the renationalization of Fannie and Freddie, however, is both correction and opportunity. We now have an opportunity to revert permanently to that mean which was our pre--1990s, indeed even our pre--1970s, system of hybrid public-.-private home finance.

\section{Republican Mortgage Market Maintenance: Paradise Regained}

'If it ain't broke, don't fix it.' So counsels the adage. Our system of home finance wasn't 'broke' in 1968 when the Johnson administration first altered it. Far from it: the system was phenomenally successful and was profitable to boot. But the Johnson Administration, misguidedly fearful that the nation might look 'broke' with the growth of both Great Society and Vietnam war spending, and that Fannie might

\footnotetext{
21 See, e.g., Robert Hockett, 'Six Years on and Still Counting: Sifting Through the
} Mortgage Mess, ' 9 Hastings Business Law Journal 373 (2013). For more, including on the author's proposed means of addressing the crisis while it was still under way, see Robert Hockett, 'What the New Treasury Must Do,' 35 Cornell Law Forum 4, (2008); Robert Hockett, 'Bringing It All Back Home,' 36 Fordham Urban Law Journal 427 (2009); Robert Hockett \& Michael Campbell, The Home Mortgage Bridge Loan Assistance Act of 2011 (New York City Bar Association, 2011); Robert Hockett, 'It Takes a Village: Municipal Condemnation Proceedings as Underwater Mortgage Cure,' 18 Stanford Journal of Law, Business, and Finance 121 (2013); Robert Hockett, 'Paying Paul and Robbing No One: An Eminent Domain Solution for Underwater Mortgage Debt,' 19(5) Current Issues in Economics and Finance (Federal Reserve Bank of New York, 2013); Robert Hockett, 'We Don't Follow, We Lead: How New York City Will Save Mortgage Loans Nationally By Condemning Them Locally,' 124 Yale Law Journal 131 (2014). 
face fallout from earlier financial market turmoil in 1966, spun it off. That of course raised a new quandary: Fannie's sheer size and systemic importance would have lent it both monopoly power and implicit 'too big too fail' status, which are both recipes for market abuse and moral hazard when the entity in question is privately owned and profit--driven.

The Johnson and then Nixon Administrations sought to mitigate these dangers through three strategies. First, some of Fannie's book was kept public in the form of the book of the newly formed Ginnie Mae, which remained unambiguously citizen-owned. Second, Freddie, a newly formed Fannie--like entity, was established specifically to operate in parallel with Fannie. Third, the federal government retained a partly governing role in both Fannie and Freddie via board representation, which was exercised more actively in the early days of the 'private' period than it was subsequently. And finally fourth, Fannie and Freddie were likewise carefully regulated over the first several decades of their 'private' lives, almost as if they were latter--day 'SIFI's or public utilities.

The problem lay in that 'as if.' In the gap between 'as if' and 'as is' lay ambiguity, ambivalence, and consequently ever-present danger. The danger was twofold. First, gargantuan duopolists are as prone to moral hazard as monopolists when operated privately for profit on the one hand and implicitly publicly guaranteed against failure on the other hand. And second, reliance on regulation alone, be it done internally via board representation, externally via executive agency, or both, is reliance on a quite fragile reed. For in the American polity regulations are far less 'sticky' than institutions, meaning that monopoly".' or duopoly-mitigation by regulation will be ever precarious. If a public utility's needed, then, better that it be publicly provided than that it be merely publicly regulated. Better, in other words, that it be reconsolidated and forthrightly restored to its original status as a straightforward citizen-"owned instrumentality.

Is a public utility needed to make secondary markets in mortgage loans, though? Could we just as well solve the problem of GSE--ambiguity by simply breaking up and spinning-off GSEs into many small purely private entities rather than consolidating and restoring them to their original status as one unambiguously public entity? I don't think so, and my reasons are readily found in the past eight decades of GSE history as recounted above.

For one thing, real estate is of course local, and property law remains state-based. That will not change for the foreseeable future. Ditto, more or less, title registration, foreclosure procedures, and like matters. This means that only very 
large--scale loan aggregators are apt to be able to diversify sufficiently to make stable secondary mortgage loan markets in respect of long-term self--amortizing, fixed-rate American mortgage loans. ${ }^{22}$ The interest rate risk entailed by loans of this kind likewise militates in favor aggregation by large aggregators able to manage suchrisk either by hedging or by operating on the federal balance sheet. ${ }^{23}$ The industry is, in other words, in the nature of a natural monopoly or oligopoly, meaning that fragmentation won't do and wouldn't last were we to try it. We are probably stuck with the choice between publicly owned or publicly regulated utility.

Unlike real estate and property law, commercial banks and thrifts $n$ the U.S. are not geographically restricted as they were in the 1930s. That all changed in the waning years of the 1990s. But commercial banks aren't our primary mortgage originators in any event, and those institutions that are remain largely small--scale and localized as they were in the 1930s. The fates of the mortgage operations of the larger institutions that tried their hands in the years leading up to the $2008 \mathrm{crash}$ the likes of Bank of America, Countrywide, Wells Fargo, and their ilk - suggests that there might be significant advantages, presumably information advantages, to localized origination combined with fully national (if not indeed global) secondary market making. If so, then the changes we've seen in banking law since the 1930s do nothing to undercut the proposition that further fragmentation rather than public consolidation of the home finance GSEs is not the way to go.

Finally, as I have noted that both the 1930s' and our more recent experiences demonstrate, home prices are what I have elsewhere dubbed 'systemically important prices and indices,' or 'SIPIs. ${ }^{24}$ These are prices that pervasively affect other prices, and that either anchor or upset financial and broader macroeconomic stability according as they themselves remain stable or fluctuate. SIPIs cannot be left to the vagaries of decentralized market dynamics, particularly when these are subject to information gaps, recursive collective action problems, and consequent procyclicalities. ${ }^{25}$ They are the ultimate in externality."generative phenomena, and accordingly objects of public concern in need of regular calibration through exercises of collective agency in the name of us all.

22 For more on this, see William Fry and Robert Hockett, "The Simplified Mortgage and Recorded Title ('SMART') Act of 2018' (blueprinting, and explaining the need for, a national blockchain mortgage registry).

23 See again supra, note 12 , and accompanyingtext.

24 See again supra, note 11 , and accompanyingtext.

25 See Robert Hockett, 'Recursive Collective Action Problems: The Structure of Procyclicality in Money and Financial Markets, Macro.-Economies, and Formally Similar Settings,' 3 Journal of Financial Perspectives 1 (2015). 
We as a polity have more or less explicitly recognized the systemic importance of at least one SIPI: That is the money rental, or 'interest' rate, which we instruct the trading desk of the Federal Reserve Bank of New York to fine--tune every morning through open market operations in the market for Treasury securities. ${ }^{26} \mathrm{I}$ suggest that in any self."consciously middle class republican polity in which homes are both shelters and the principal assets held by the bulk of the citizenry, home prices are at least as systemically critical as interest rates. That is so true that public determination of money rental rates themselves is often justified partly by reference to their influence on home prices, which are widely observed to be sensitive to interest rates. And this no doubt is also why mortgage instruments are the one financial asset additional to Treasuries that the Fed has targeted in its quantitative easing ('QE') efforts - specifically, in QE3. ${ }^{27}$

It would seem, then, that we should be thinking in terms of large public instrumentality that operates vis-"à-"vis mortgage loans much as the Fed does vis--à̀-" vis Treasury securities. In both cases the markets involved both are and must be enormous. And in both cases the prices involved are far too systemically important to leave to the vagaries of chaotic buying, selling, and procyclical herding that characterize markets with countless small players confronted with frequently unavoidable but quit consequential information gaps. ${ }^{28}$

It seems to me no accident both that it took public market intervention to establish a secondary market for long-term self-amortizing mortgage loans and thereby spread home-"ownership over two-thirds of our citizenry in the first place, and that those market-making institutions have remained quite gargantuan in size ever since. The only real question, then, seems to be whether we should now restore carefully regulated but still profit-seeking private GSEs plagued by moral hazard, or restore once-"again unambiguously public GSEs that operate in the name of the public rather than for profit even while following sound actuarial practice. As suggested above, the latter option seems to me clearly preferable. Regulations, again, often change quickly. Institutions are harder to alter in fundamental ways.

We should think of our secondary market maker in home mortgage loans as a sort of 'housing price Fed,' charged with maintaining maximum homeownership as

\footnotetext{
26 See, e.g., Robert Hockett \& Saule Omarova, "'Private" Means to "Public" Ends:

Governments as Market Actors,' 15 Theoretical Inquiries in Law 53 (2014).

27 Id.

28 See generally Robert Hockett, 'A Fixer--Upper for Finance,' 87 Washington University

Law Review 1213 (2010).
} 
consistent with stable home prices much as the Fed is charged with maintaining maximum employment as consistent with stable consumer prices. ${ }^{29}$ The precise institutional expression to be given that vision might be any of several options, but one in particular would seem to require the least institutional disruption: fold Fannie and Freddie back into Ginnie. For Ginnie, recall, is precisely what's left of the original Fannie - that portion of its book which was kept on the federal balance sheet, and has remained there, waiting to be reunited with the rest of the portfolio, ever since.

\section{Conclusion}

Sometimes a product, after years of refinement, reaches so nearly complete a state of perfection that most putative 'improvements' thereafter just muck up a perfectly fine thing. The 'classic' case - in a sense, literally - might well be Coca Cola's ill-.fated experiment with replacing its original formula, now sidelined as 'Coke Classic,' with a new formula in the late 1990s. The experiment failed - sales plummeted, the public clamored for restoration of the status quo ante - and Coke ultimately saw wisdom in a return.

I've argued here that our home mortgage GSE story is much like the Coke story, only far less trifling and far more consequential. The crash, crunch, and debt.-. deflation we've recently seen was calamitous, taking many human lives along with the trillions in lost wealth it occasioned. Yet it was altogether avoidable and unnecessary, precisely because we'd been through it before and had left ourselves fine institutions to prevent a recurrence. The most important such institutions but one are still with us, functioning much as they've done for the past eighty years.

The one we mucked up we mucked up for bad reasons, and is the one that we ought now restore. It continues a diminutive shadow existence currently as Ginnie Mae, the true functional successor to Fannie Mae. Meanwhile an ersatz Fannie, along with a misbegotten sibling named 'Freddie,' hide sheepishly once more on the federal balance sheet they should never have left, like expats who seek to come home and await their lost passports' recovery.

In a polity founded as a republic as ours was, in which republican ideation and ideology continue to shape thinking and ground affect as they do among us,

29 I am of course alluding to the language of the Fed's mandate, as formulated in Section 2A of the Federal Reserve Act. 
home--owning is apt to carry deep cultural resonance indefinitely into the future. This is who we are. Our 'homesteads' make us American as surely as the Royal Family makes Britain British or the Ganges makes India Indian. By the very same token, home prices are accordingly by far the most pervasively influential and macroeconomically significant - the most systemically important - of all prices save those of our Treasury securities in our economy.

We seem at last to have grasped this, how ever inchoately, by the end of the traumas of the 1930s. We should never have forgotten it. And it's time now to restore it. Though restoration could take many forms - making the Fed, for example, a secondary mortgage market maker, or restoring the old Home Loan Bank system the simplest course seems to be simply to reunite Fannie, Freddie, and Ginnie by recombining them all into one public instrumentality. An instrumentality that doesn't operate for profit, but for widespread republican home-"-owning among all who both wish and are reasonably able to do it, and that stands ready to purchase and take on the interest rate risk of all long-term self-amortizing fixed--rate mortgage loans that meet sound actuarial standards.

Call it Fannie, as it was until 1968, or call it Ginnie, as its original core is called now; but what ever you call it, call it ours. 